\title{
SUCCESSFUL MANAGEMENT OF SETTLEMENTS TO BOOST RURAL DEVELOPMENT
}

\author{
Tamás Tóth¹, József Káposzta²
}

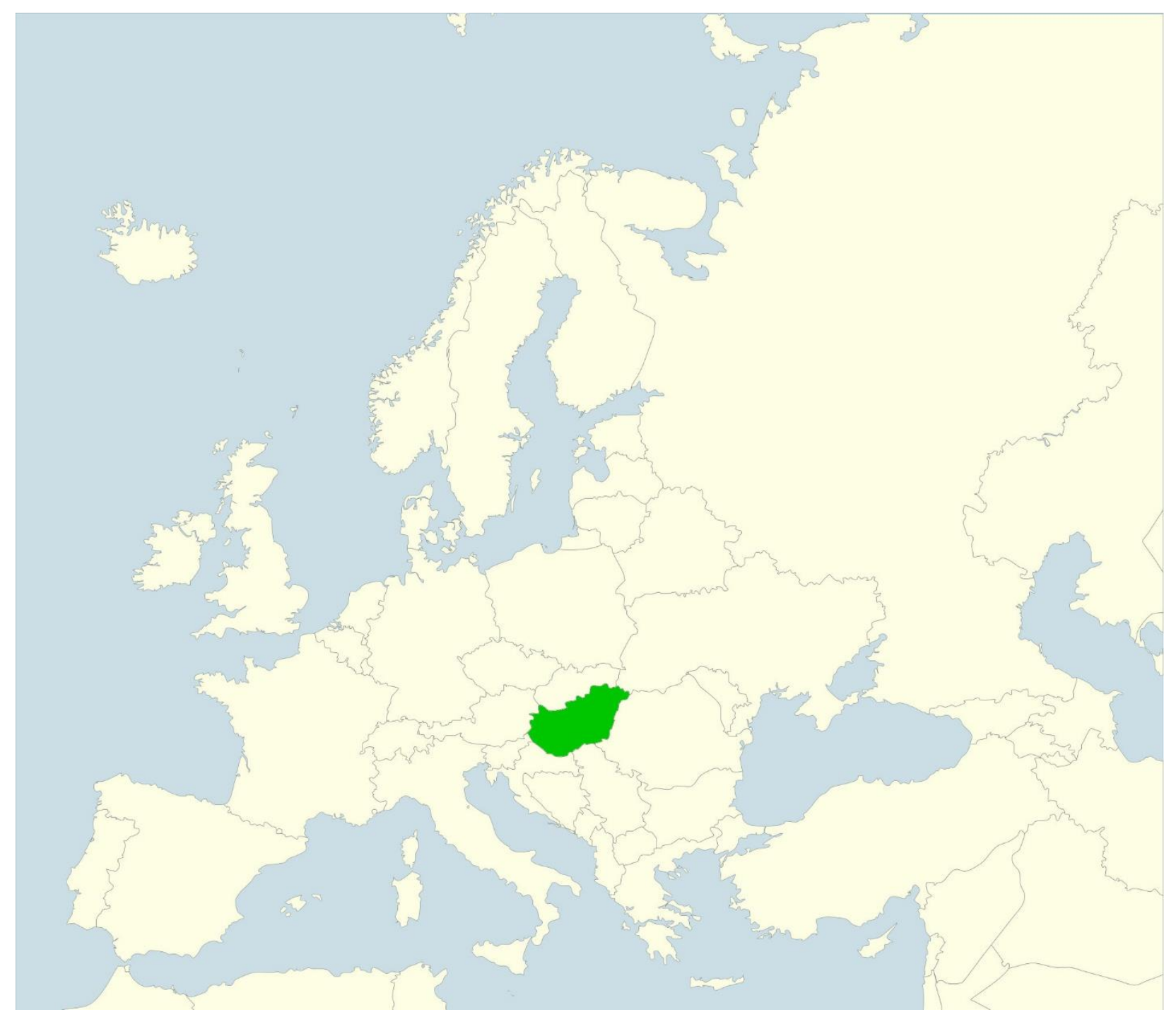

1 Prof. Dr. Tamás Tóth, Kodolányi János University Budapest, Hungary; ORCID: 0000-0002-1851-0434, e-mail: toth.tamas@kodolanyi.hu

2 Prof. Dr. József Káposzta, Hungarian University of Agriculture and Life Sciences Gödöllö; ORCID: 0000-0002-12398541, e-mail: kaposzta.jozsef@uni-mate.hu 
Abstract: The paper summarizes and provides and overview on the economic and social processes influencing and supporting the successful management of settlements, focusing on Hungary. The role of leadership and settlement management is inevitable in the everyday operation as well as in the definition and realization of development concepts and strategies. The basis of stable operation and development is the financial independency and stability, thus we need to call the attention on the importance of economic development functions of settlements as well as on the important role of mayors and leaders in the economic and spatial development. The approaches, the ideas as well as the way how the leaders think are all determining factors in development. Nowadays, settlement development and regional economic development raise such key issues that are also the main research questions in our paper, like „What does a good municipality/a good settlement look like? How can "good' be described?" What are the main characteristics of a suitable leader in the case of settlements? It is known that there are no targeted trainings, courses for mayors/heads of municipalities to prepare them to be good leaders, there are no nationally or internationally acknowledged skills, competences that could be applied to select the most suitable leaders for the positions. Therefore, we believe that we must call the attention to this shortage and motivate the experts in public administration, the researchers and scientists, as well as trainers and coaches to cooperate and work on the solution. In this paper, through the dimension of leadership/management, we intend to discover the characteristics of successful community leaders and to focus on the importance of the activities of 'local heroes', who prove to have strong commitment to the development of settlements.

Key words: settlement development, municipality, management, safety, community

\section{Highlights:}

- Efficient and sustainable operation of settlements determine the welfare of their population.

- Settlement management is inevitable in realizing the development strategies.

- Without well-thought and proper planning, there is no efficient leadership.

- Successful settlements cannot exist without qualified and spirited leaders.

- There is no collection of characteristics, abilities of successful settlement leaders.

\section{Introduction}

Nowadays, many experts think that the management of a successful settlement is a public issue and it is also generally accepted that an efficient and resource attracting local economy is inevitable to manage a settlement successfully. To maintain and operate the local economy in security and sustainably in long terms is one of the key issues of the local society and the local community.

We agree with the statement of Szilágyi and Boldizsár (2016): Due to the creation of rural security consciousness, people not only recognize, appreciate and understand the opportunities of rural areas and secure environment, but they also use such opportunities and actively influence them. The law also allows conscious, especially security-conscious, citizens to contribute to the complex security both at micro- and macro-levels. Recognizing all the dimensions of rural security and handling them in a dynamic unit bring new way of thinking, new approaches, responsibility and economic opportunity as well. Therefore, the security of the country, cities and rural areas is a key to the stability, security and development of a state. A good state must guarantee not only the basic conditions for life but must make efforts to improve the quality of life and the competitiveness of rural and urban areas, making them better places for life. Bottom-up 
approach enables the state to carry out those tasks, since without successful settlements, there is no successful state.

Enyedi (2004) stated that the never ending spatial changes contribute to the creation of spatial inequalities. Such changes affect the economic growth and the spatial development of the region and influence the competitiveness, as well as the population's standard of living and living conditions. Since the conditions differ from one place of the globe to the other, the development is expected to be different in terms of scope, way and speed. Such differences exist in the human, social, economic, infrastructural and environmental conditions as well. Regions, due to their various resources, stimulate the economy differently. Considering the above-mentioned, settlements play important role in generating spatial development, so we need to provide more details about the notion, interpretation of settlements.

\section{What is the term 'settlement' used for?}

Settlement is a place where people live. A settlement may be as small as a single house in a remote area or as large as a mega city (a city with over 10 million residents) ${ }^{3}$. However, in our paper, we intend to focus on rural settlements that are rather small-sized.

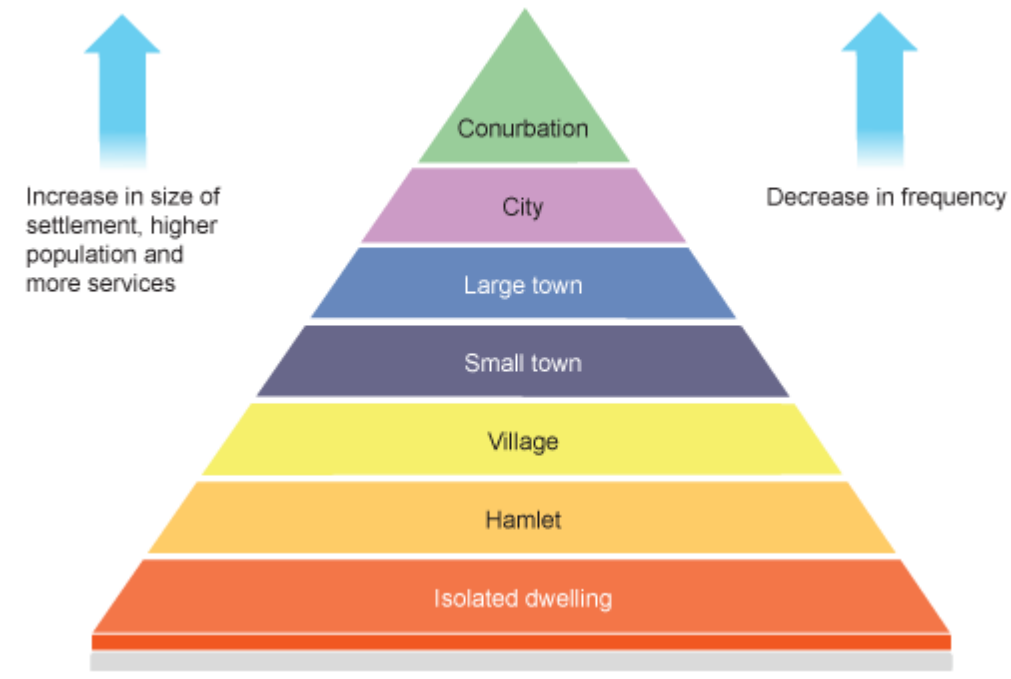

Fig 1. Settlements. Source: https://www.thegeographeronline.net/settlements.html

Settlements are artificially created base-unit of the social space in various sizes, where the most important and most common economic and social functions, so-called 'social basic functions', are spatially concentrated. Such social basic functions are e.g., housing, jobs, participation in education/training, activities necessary to sustain life (e.g., shopping) as well as leisure time activities (Berényi, 1992). The latter ones are optional (e.g., shopping, spending time on the beach etc.) or forced by external conditions (e.g., managing issues in public administration).

\section{Typology of settlements}

From legal approach, settlements are towns and villages. Both categories apply the terms for the core areas (centers) and the peripheries, moreover, larger towns can be divided into further public administration units (districts, parts of towns).

Classification according to size and housing density:

Size and housing density are used together with settlement functions to classify settlements into major categories i.e., rural and urban. Rural settlements are often small in size and have low housing and population densities. Urban settlements are larger in size and have many houses

\footnotetext{
${ }^{3}$ (https://www.thegeographeronline.net/settlements.html)
} 
built close together. Rural settlements can further be broken down into these four grades on the basis of size; homestead, farmstead, hamlet and village. An important indicator is the distribution of settlements by size. (Köszegfalvi-Lloyd 1999; Illés 2008).

- A single homestead just has one compound, usually isolated and owned by a family, and one may be many kilometers from the next.

- A farmstead consists of two or more homesteads, usually dispersed in a farmland and occupied by up to fifty individuals.

- A hamlet is made up of several dispersed, nucleated or linear homesteads generally with shops, schools or other service centers and occupied by some hundreds of persons who are engaged in primary activities like farming, hunting and fishing.

- A village, like a hamlet, may be dispersed, nucleated or both nucleated or linear, but the village has more homesteads and the population may be up to several thousands. The people engage in primary occupations, but there may also be craft and cottage industries, and service centers like schools, post offices, health centers and markets.

- Urban settlements can equally be graded into four, according to size. These are towns, cities, conurbations and megapolises.

- Towns are urban settlements of up to several thousand persons. Houses are built together and the emphasis is more on secondary and tertiary rather than on primary occupation. Usually, a town has large chain stores, and many other social and commercial facilities.

- Cities are the major towns of a country, like the major state capitals which have administrative functions. The old concept of a city being a walled town is no longer tenable as cities are no longer walled these days. They are generally larger than towns.

- A conurbation grows when two or more towns or parts have grown and joined together to form a large urban area of 1 million persons or thereabouts. The boundary between original towns becomes blurred, just like we have in Lagos (Ikeja) and Accra (Tema).

- Megapolises are several cities or conurbations which have grown over the years and have joined together to form a massive sprawling urban settlements. Such settlements stretch over several square kilometers and, as conurbations, it is difficult to know where one original city ends and the other begins. Megapolis is the highest in the hierarchy of urban settlements. Examples are New York-Boston-Philadelphia and Greater Los Angeles (USA), Tokyo (Japan), Greater London (Britain), Mexico City (Central America), and Dusseldolf-Duisburg-Essen-Dortmund, in the Rhur manufacturing region of Germany. (Hornby - Jones, 1990; Tiner, 2008). 


\section{Theoretical background}

In our paper, we examine the operation of settlements, the changes in the settlement system in various timeframes based on highly acknowledged experts and researchers. We also introduce the 4 strongest dimensions of settlements (Figure 2).

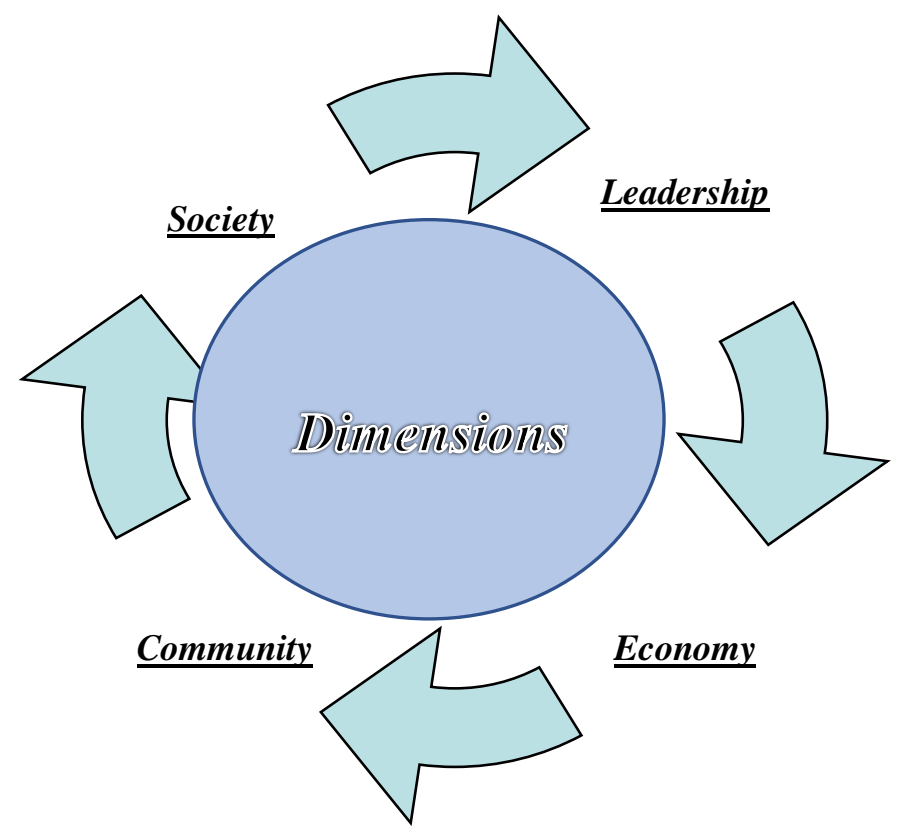

Fig 2. Dimensions determining the success of settlements. Source: Tóth, 2019.

Analysis must be done along the four dimensions because we believe that successful operation of municipalities is based on stable and efficient local economy and a flourishing society that appreciates and generates community values. In this paper, we go into deep regarding the leadership/management dimension. One of the most significant factors forming the economy and society is the change in the conception of security. Based on our research as well as on literature, we can state that the economic and social dimensions of successful settlement are representing more and more values. Thus, the interpretation of economic and social dimensions of settlements is emphasized especially when considering successful settlements/areas as well as the development measures.

Based on all these, we think that the aims, measures and sources of development policies are able to solve the social and economic problems of settlements and by creating good standard of living and income conditions, they are able to contribute to their competitiveness needed for efficient and secure operation. However, the operation and maintenance of settlements, as well as supporting the efficient economic and social dimensions are our common issues and all players have duties and responsibilities - either direct or indirect.

While examining the economic dimension, we must not forget that there is only one sure thing in our economic and social environment, namely the change. Factors influencing our everyday life are always in change at both local and global level. Except for the spontaneously changing spaces, spatial policy, rural policy and sectoral policy makers also generate and influence such changes. Therefore, we need to interpret those processes that could serve as basis for efficient economic development. However, the existing huge differences between settlements mean serious challenges for the leaders. We must also take into consideration that there are different sized settlements with even more differences regarding their economy and society. Many forecast that the world's population will exceed 9 billion by 2050 and the majority of the population will be crowded in megapolises and such complex development policies must be applied in those settlements, which might go beyond even the size of certain countries. In long terms, it seems that settlements of 30-40 or even 50 million population must be maintained and managed. We need to take the fact into account (based on empirical data) that the national income sharply 
increased in the last 30-50 years in the developed industrialized countries, while the general satisfaction, the well-being of people remained the same...

As examining the social dimension, we may come to the conclusion (following the abovementioned thoughts) that as the methods develop, we are able to measure the individual and social welfare more precisely. Researchers usually refer to material welfare, while well-being also reflects the emotional and conscious approach of individuals to the quality of their own life. There has been a concept in regional policy for long that in addition to hard factors, soft factors and their relationships have to be considered while examining the development level of areas. The examination of individuals' well-being can be measured with survey technics and such information can supplement the other secondary data.

The importance of the community dimension is obvious in spatial development, though the reality is yet far from theory. Since it spreads in practice slowly, it is difficult to build it in the development processes. It makes them slower, more complicated and expensive but it allows them to get real solutions for real needs.

It is unfavorable that the members of community are not often involved in the development processes, not only because democracy in practice is more expensive and more difficult process but because most of the leaders wish to achieve results as soon as possible and they do not wish to tolerate long preparatory phase. Meeting the community needs and expectations are inevitable during the planning and the realization phases. Community planning (involving the community in the planning) is able to be more successful than the method only discussing the available traditional plans. Such community planning results plans that are accepted and acknowledged by the society to a much large extent.

\section{The coherence between the good local governance and the efficiency of local leadership (leadership/management dimension)}

The role of the settlement management is inevitable in the maintenance, especially in the everyday operation as well as the designing and realization of development ideas. In Hungary, several empirical studies have been conducted on the state of competences in local government management (e.g., the KÖFOP-2.3.3-VEKOP-16-2016-00001 "Local Competitiveness Development Research Program"). A lot of researchers state that, of course, local government competences are not the only factor contributing to the development of competitive municipalities, but they are of particular importance in rural areas, where the presence of the civil sector and the involvement of the business community in public affairs are usually not very strong. The basis of stability and development is the financial independency and stability, thus we must call the attention to the importance of economic development tasks, as well as the determining role of leaders. The ideas and approaches of leaders play dominant role in the development of settlements. Nowadays, settlement development and regional economic development raise such key issues like: „What does a good municipality and good settlement look like? How can they be described?" Through the leadership/management dimension, we discover the characteristics and features of successful community leaders and try to introduce the importance of the activities of "local heroes".

It is important what approaches the leaders have towards developments and the shaping of the future. They also must have necessary and proper abilities and skills to be successful. In his researches, Salamin (2018) managed to discover the key competences necessary for efficient spatial planning in Europe. Of course, they are not key competences only on the continent but can be generally accepted (Figure 3).

Regarding Hungary, we need to mention that the possession and use of the abovementioned key competences would be a minimum expectation towards the experts in planning and development as well as for the people at municipalities in responsible positions. However, we know what difficulties and challenges the experts face in spatial planning. Moreover, in many countries, there is no legal frame for the qualifications, knowledge, licenses regarding the experts working in spatial planning and development. 
1. The basic logic of planning

2. Socio-economic spatial systems

3. Built environment

4. Environmental spatial system

5. Planning techniques

6. Planning ,products"

7. Planning tools

8. Independent research
- Creative vision

- Initiating and implementing actions

- Project management

- Problem solving

- Collaborative and multidisciplinary work

- Professionalism

- Communication skills

- Dissemination of knowledge transfer from research and practice

Fig 3. The key competences of spatial planning in Europe. Source: Salamin, 2018

\section{Settlement management}

Several researchers were dealing with the interpretation of the concept. We agree with the definition of settlement management by Tiner (2008). According to him, it has double meaning: on the one hand, it covers the organization, planning, leadership and marketing activities carried out by the local government to maintain the settlement („maintenance”), on the other hand, it covers the group of leaders („management”) who are responsible for the appropriate operation, the harmony of leadership tasks as well as the targeted activities. Tiner also calls the attention to the hard and soft components of settlement management.

Hard components include:

- strategies of the local government (fundamental settlement development aims, including the tasks, instruments, activities and resources),

- the structure of the local government (organization of tasks, authorities and responsibilities),

- systems of municipality organization (planning, budgetary, economic, information and interest systems, etc.).

\section{Soft components are:}

- common values (the most important views, values accepted by the majority of municipality players),

- the personnel (the mayor, the members of local government, the representatives, the civil servants etc.),

- abilities (ability of the local government as one unit to fulfil all its tasks),

- the style reflecting the level of organizational culture (behavioral modes characteristic to the local government as a whole, influencing its operation) (Tiner, 2008).

According to the theory of Keynes, which was the most determining stream in the regional growth theories of the $60 \mathrm{~s}$ and $70 \mathrm{~s}$, market automatisms do not operate immaculately, they are able to create balance only in certain cases (Jóna, 2013). In their growth theories, Domar (1946) and Harrod (1939) pointed out to the fact that investments promote market expansion, have impact both within and outside the supply chain, eventually support growth, but its efficiency is highly determined by the quality of management.

The most important power in shaping the economic, social processes of settlements may be the local leadership. In case leaders in the local government, the mayor, the representatives fulfil their tasks well, have proper overview on the economic and social processes, they are able to manage the settlement successfully and efficiently. Sometimes, it is not the case, since not all 
the leaders of settlements think that they need to be an active player in the economic or social issues. In general, they carry out very few tasks that are beyond the ones recorded in the law.

We must also remember what Oláh (2017) wrote in her dissertation, namely that each settlement is an individual and unique one. „Every settlement has its own character. Every settlement has its own past and present, determining its future. Therefore, creating clusters of proper and homogenous settlements is not possible without mitigating the individual characters. In order to draw consequences even on a small group of settlements based on a few factors, we need to know each settlement in the group as well as the relationship and processes between them and with other settlements outside the group, either they are visible or not, direct or indirect ones". It means that each settlement has its unique character, thus there are no settlements that would be the same. What is the conclusion? Individual, tailored instruments must be applied in each settlement. Of course, the combination of instruments may differ. We may observe similarities but special, individual solutions have to be applied to each settlement. Certainly, it does not mean that economic development does not have to be a well-thought process.

We can agree that the aim of spatial policy is to analyze the spatial characters of the economy and society. About a decade ago, a new concept emerged in spatial policy, namely the spatial capital. The spatial capital reflects individual features of the different areas, since they concentrate the elements of spatial capital in various ways e.g., because of their geographical location, size, natural resources, built heritage, infrastructure and social capital. „Spatial capital is the group of characters that are location/area-specific, thus directing the development policy to put the local values in focus and to renew them continuously." (Rechnitzer and Smahó, 2011; Káposzta et al. 2015; Nagyné, 2013; Goda and Kassai, 2011; Horváth, 2013). Uniques values might be the social activity of the community, the local economy, infrastructure, environmental conditions and the receptive ability towards the opportunities from external material and intellectual goods (Goda and Tóth, 2013; Goda et al. 2013). Unique values of settlements are really important, since they influence their economic success and the standard of living of the population (Káposzta, 2001; Ritter et al. 2013).

The development of rural local leadership has been specifically identified as an aim in many policies, including those concerning health, economic development and environmental management, and as being an important means by which communities can adapt to change (Haslam McKenzie, 2002; Department of Local Government and Regional Development, 2002). This role for rural leadership is also supported by the findings of recent case study based research (McKinsey and Co., 1994; Johns et al., 2001; Epps and Sorensen, 1996; Sorensen and Epps, 1996). Leaders in rural communities have been credited with revitalizing communities, generating new economic prosperity and strengthening social bonds (Kenyon, 1999; Sorensen, 2002).

As Bakos and Bálint (2015) stated: „All the dimensions of health are necessary for the proper operation of a community, settlement or area. The most important resource is the physically and mentally healthy human, since he/she offers labour force, provides reproduction, is responsible for inheriting abilities, skills, traditions, contributes to the maintenance of institutions, to the income generation as well as represents the power of community."

In the face of the most perilous challenges of our time - climate change, terrorism, poverty, and trafficking of drugs, guns, and people - the nations of the world seem paralyzed. The problems are too big, too interdependent, too divisive for the nation-state. Is the nation-state, once democracy's best hope, today democratically dysfunctional? Obsolete? The answer, says Benjamin R. Barber in this highly provocative and original book, is yes. Cities and the mayors who run them can do and are doing a better job. Barber makes a persuasive case that the city is democracy's best hope in a globalizing world, and great mayors are already proving that this is so (Barber, 2014).

One of the much discussed issues concerning local partnerships is the participation of local people. According to the majority of experts, the participation of local actors in decision-making process is growing through the partnerships and thus wiser and fairer decisions can be made in development issues affecting them. Some Western-European case studies (Hayward et al., 2004; Bristow et al., 2008; Taylor 2000; Geddes, 2000; Lowndes et al., 2001; Kassai, 2012) confirm that 
working in a partnership does not necessarily end in real community participation and, in general, it does not automatically mean equal participation for all members.

The other central issue, in the literature related to local partnerships, is social involvement. It is widely considered that working in partnership is one of the most suitable means for fighting against social exclusion, since wide range of representatives of different sectors, even of the weaker interest groups of local communities are involved in local developments. Some research (Thuesen, 2010; Shucksmith, 2000; Buller, 2000; Scott, 2004; Shortall, 2008; Kull, 2009; Storey, 1999; Gerencsér-Tóth, 2017), however, proved that partnerships increase social exclusion rather than reducing it. In the decision-making body of partnerships, for instance, male dominance is a frequent feature. The representatives of community and civil spheres are often scarcely audible alongside the public sphere, and even if the formerly excluded local actors are involved in partnership, they are usually at a disadvantage owing to the lack of intellectual and material resources.

We are convinced that without well-thought and proper planning, there is no efficient leadership. Those, who deal with spatial development and town management, always have to face and address new challenges. They need to work on new solutions because the former ones might not be appropriate anymore and because the town management can be successful if the development is based on an established strategy, meeting the interest of the community. It must be with the efficient and intensive involvement of the community. It is not enough if the community declares which direction they would like to proceed. Such a policy is needed that is transparent and integrates the community, and efficient communication must be carried out by the town leaders in position.

The number and activity of nonprofit organizations might reflect better the social action plan and participation. We can see that in successful settlements, the number of nonprofit organizations and their activity is much higher than the county or national average. The social participation, especially its efficiency, is influenced by several factors, including the quantity and quality of human resource. In case it is reflected by the number of full-time students in higher education, it can be seen that there is a high concentration in the central region of the country (Figure 4) despite the fact that there are higher education institutions in the largest cities of the countryside as well. Such high concentration means that the countryside in Hungary often faces the challenge, the lack or the insufficient quality of qualified human resource.

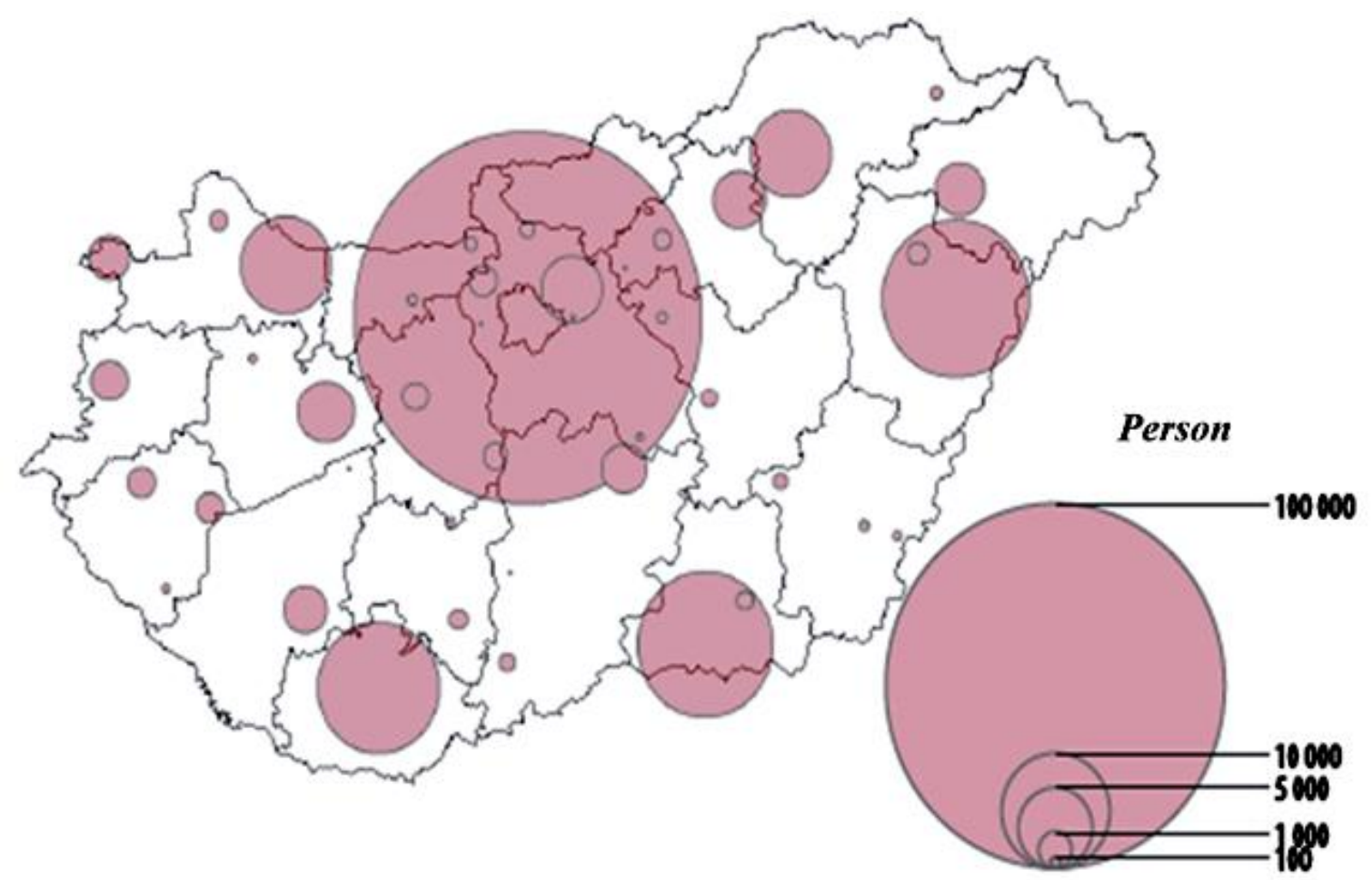

Fig 4. The number of full-time students in bachelor and master courses, 2019. Source: CSO Tér-Kép, 2019 
A good leader is someone who thinks together with his/her community, uses common language and serves common interests. A good leader raises most of the ideas that can be agreed and followed by the local community. Pásztor Béla, who has been the leader of a Hungarian town since 1965, called Veresegyház, has his own ars poetica: „We must live with the people and we must serve them" (Kovács, 2006).

\section{Integrated way of thinking}

Figure 5, which is also found in the Hungarian National Development and Spatial Development Concept, calls the attention to the importance of the future vision, the definition of aims as well as the integrated approach.

For the question „What must a settlement/region look like?" we believe that the most appropriate answer is in the abovementioned concept. Even if we do not analyze Figure 5 in details, it is obvious that it is difficult to define the path leading to a desired settlement. Agreeing with Bakes (2017), a successful settlement needs bottom-up initiatives and self-organized communities which can contribute to the development of the local economy. According to Bakos, a certain extent of self-sustainability is coded in the local communities that - with a supporting environment and through the work of the "local heroes" - can revive and maintain viably.

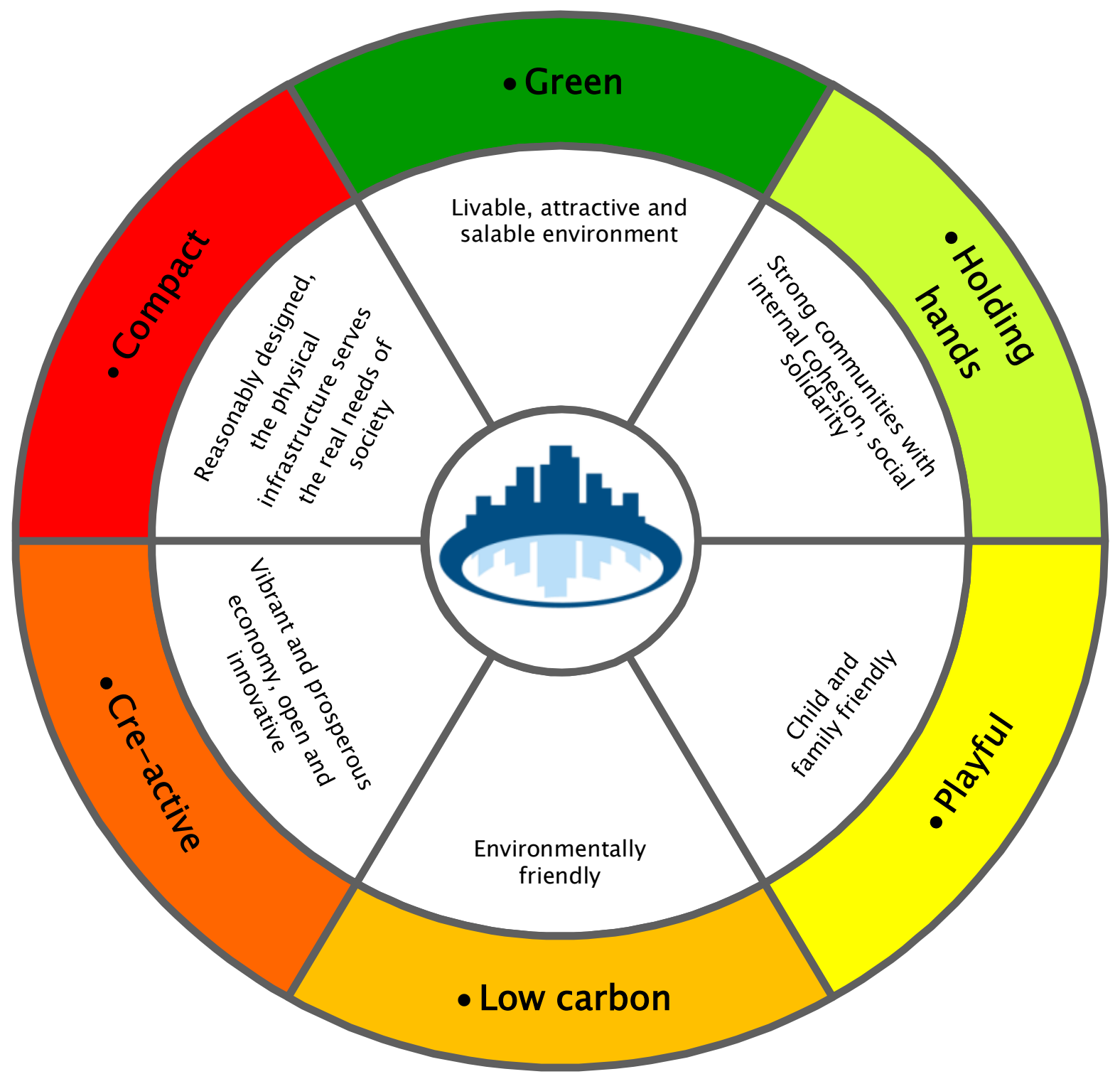

Fig 5. What should a settlement/region look like? Source: OFTK 2014 


\section{Features of successful local governments:}

- they operate the institutions for the satisfaction of the public,

- they help to increase employment,

- they create clean and healthy environment,

- they can identify the local values and

- they protect the local interests (Fekete, 2011).

If there is obvious local interest, it helps the decision-maker to identify his/her own tasks as well. Everybody is needed who is capable for a stronger community (e.g., civil organizations, churches, businesses etc.). However, the success is determined by various factors in different countries and regions. Such factors include the cooperation willingness of local communities, the amount of local taxes, the availability or lack of financial sources, the skills of local decision-makers, the distance from centrum areas, the infrastructure as well as the ability for innovation (Nagy, $2019 b$ ). Regarding innovation, not only the final product/service/activity/structure is important but the way how we get there. Innovation can be generated by many people (businessmen, local municipality, civil associations, research groups, higher education institutions, governmental authorities) or by the cooperation of those (Nagy, 2019a). Regardless of the innovator, we know that the innovation will reach people, but the most important question is when. According to the modern interpretation of innovation, it may cover such various things that it does not necessarily require high amounts of financial resources and it often moves bottom-up. For instance, such innovation can be a new way of community development that is desired by the local population, applying new methods. However, it must be underlined that an innovator (a person or a group) is inevitable in the process, who motivates, encourages and manages the innovative projects (Nagy, 2019a).

Referring back to the issue of security and stability, we need to mention that in the settlement mentioned above, Veresegyház, the stability and the constant factor is the mayor himself, leading the town for more than 50 years, which is a solid foundation for the developments. His strength is that he was able to help the town to adapt to the ever-changing conditions and circumstances in a flexible way.

When analyzing the efficiency of operation of settlements, the local tax income must also be examined (Figure 6). In successful settlements, there is sufficient economic structure, thus the local businesses are able to contribute to the operation of the settlements.
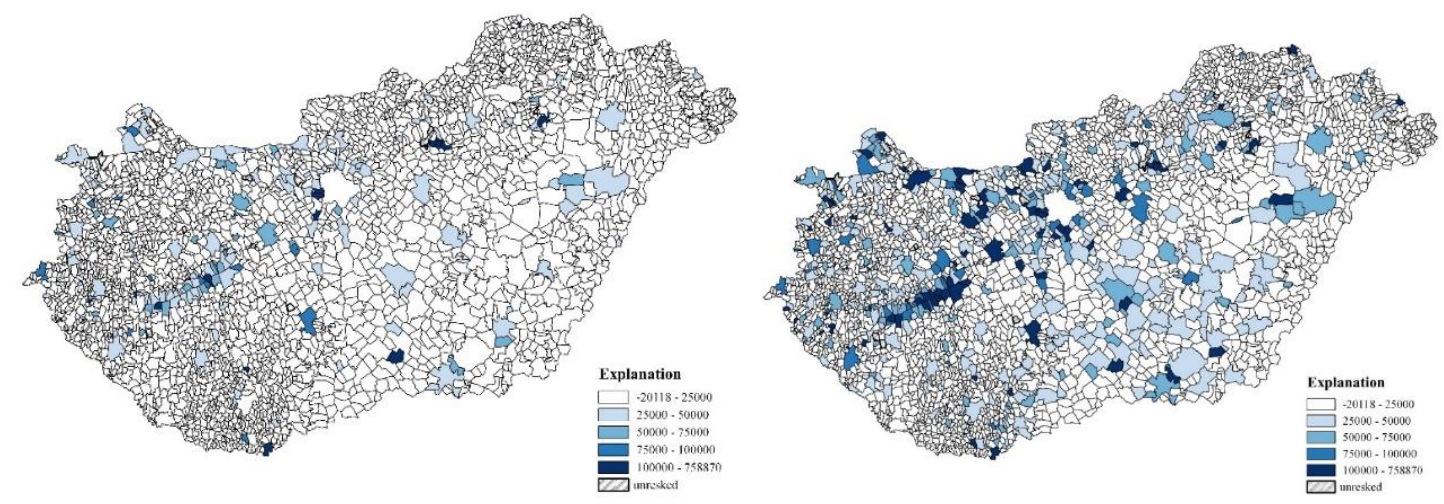

Fig 6. Local tax income of municipalities (1,000 HUF) per 1,000 inhabitants, year 2009 and 2019. Source: CSO data, own editing, 2020.

If the leaders focus on the above-mentioned issues, the settlements can obtain higher income from taxes and can use it to meet the community needs. Figure 6 reflects that many Hungarian settlements managed to realize sharp increase in the amount of income from taxes, though there are significant spatial inequalities. 


\section{Conclusions}

Regarding the management/leadership dimension, we need to fix that successful settlements cannot exist without clever and spirited leaders. "Real" settlement leaders are strongly committed to their communities, they are ready to respect and serve the people. They have clear ideas about the future vision that is declared in writing and is communicated to the members of the community and is not only in theory. While building the community, their personal relations greatly assist the development and can be exchanged to financial capital. It is an advantage if leaders had worked in public administration earlier and gained experience from various fields of life. If there is an obvious and clear local interest, the decision-makers also know what their job is. It is inevitable to involve everyone who is able to do things to strengthen the community (e.g., civilians, churches, corporations, etc.) so that the mayor could manage the settlement consciously, proactively and with all-encompassing attention. His decisions are always firm, and most of them live up to their hopes. Of course, this development path is with no end, everything can always be further improved, the efficiency of city management can be further increased. They have the courage and intention especially in times of difficulties. In addition to personal characteristics (that are necessary for the good leadership), the existing skills, abilities can all be further developed by appropriate education. We would fully support the compilation of a list of skills, competences, required knowledge for those who intend to become the leaders of rural settlements that could be adopted to the local specialties and needs internationally. Our aim in this paper was to point out the characteristics of settlement leaders who determine the success of the settlements, including the life of their citizens. We are convinced that characteristics, competences mentioned above are valid for all the countries, even if our experience is mostly related to our mother country, Hungary.

\section{Academic references}

[1] Bakos, I. (2017). A lokális élelmiszerek fogyasztói megítélése és innovatív értékesítési lehetősége. A Falu, 32, 5-14.

[2] Bakos, I. M. \& Bálint, Cs. (2015). Egészséges (?) Hollókő. In Nagyné, M. M., ed., Acta Regionis Rurum, vol. 9 (pp. 92-103). Gödöllö: Szent István Egyetemi Kiadó.

[3] Barber, B. R. (2014). If Mayors Ruled the World: Dysfunctional Nations, Rising Cities. New Haven: Yale University Press.

[4] Berényi, I. (1992). Az alkalmazott szociálgeográfia elméleti és módszertani kérdései. Budapest: Akadémiai Kiadó.

[5] Bristow, G., Entwistle, T., Hines, F. \& Martin, S. (2008). New spaces for inclusion? Lessons from 'three-thirds' partnerships in Wales. International Journal of Urban and Regional Research, 32(4), 903-921. DOI: 10.1111/j.1468-2427.2008.00822.x.

[6] Buller, H. (2000). Re-creating Rural Territories: LEADER in France. Sociologia Ruralis, 40(2), 190-199. DOI: 10.1111/1467-9523.00141.

[7] Domar, E. (1946). Capital expansion, rate of growth, and employment. Econometria, 2(4). 137-147. DOI: 10.2307/1905364.

[8] Enyedi, Gy. (2004). Regionális folyamatok a posztszocialista Magyarországon. Magyar Tudomány 111(9), 935-941.

[9] Epps, R. \& Sorensen, T. (1996). The nature of leadership in rural Australia: A case study of four central western Queensland towns. In Lawrence, G., Lyons, K. \& Momtaz, S., eds., Social Change in Rural Australia (pp. 154-166). Rockhampton: Central Queensland University Press.

[10] Geddes, M. (2000). Tackling social exclusion in the European Union? The limits to the new orthodoxy of local partnership. International Journal of Urban and Regional Research, 24(4), 782-800. DOI: 10.1111/1468-2427.00278. 
[11] Gerencsér, I. \& Tóth, T. (2017). „Lesz ez még így sem” avagy a településvezetők szerepe helyi fejlesztésekben két település példáján keresztül. Studia Mundi-Economica 4(4), 2-11.

[12] Goda, P., Káposzta, J. \& Péli, L. (2013). Case study on spider-net enthrophy investigation in rural areas. Review on Agriculture and Rural Development 2(1), 296-300.

[13] Goda, P. \& Kassai, Zs. (2011). A 2004-2010 közötti gazdaság - és regionális fejlesztő operatív programok összehasonlító kistérségi vizsgálata. Gazdaság és Társadalom 2, 93110. DOI: 10.21637/GT.2011.2.07.

[14] Goda, P. \& Tóth, T. (2013). Pókháló- entrópia, mint új rendszervizsgálati megközelítés a területi elemzésekben. Területi Statisztika, 53(2), 169-189. DOI: 10.15196/TS560101.

[15] Harrod, R. F. (1939). An Essay in Dynamic Theory. The Economic Journal, 49(193),14-33. DOI: $10.2307 / 2225181$.

[16] Haslam McKenzie, F. (2002). Leadership development: flogging a dead horse or the kiss of life for regional Western Australia? Sustaining Regions 1(2), 21-31.

[17] Hayward, C., Simpson, L. \& Wood, L. (2004). Still left out in the cold: problematising participatory research and development. Sociologia Ruralis, 44(1), 95-108. DOI: 10.1111/j.1467-9523.2004.00264.x.

[18] Hornby, W. F. \& Jones, M. (1990). An Introduction to Settlement Geography. Cambridge University Press.

[19] Horváth, E. (2013). Kicsik között a legkisebbek - a törpefalvak sikerességének kulcstényezői [PhD. Thesis]. Győr: Széchenyi István Egyetem. DOI: 10.14232/phd.3950.

[20] Illés, I. (2008). Regionális gazdaságtan. Területfejlesztés. Budapest: Typotex Kiadó.

[21] Johns, S., Kilpatrick, S., Falk, I. \& Mulford, B. (2001). Leadership from within: rural community revitalisation and the school-community partnership. Youth Studies Australia 20, 3-9.

[22] Jóna, Gy. (2013). A területi töke kistérségi jellegzetességei [PhD thesis]. Gödöllö: Hungarian University of Agriculture and Life Sciences.

[23] Káposzta, J. (2001). Regionális gazdaságtan. Gödöllö: Szent István Egyetemi Kiadó.

[24] Káposzta, J. (2016). Regionális összefüggések a vidékgazdaság fejlesztésében, Studia Mundi-Economica, 3(1), 52-61. DOI: 10.18531/Studia.Mundi.2016.03.01.52-61.

[25] Káposzta, J., Ritter, K. \& Kassai, Zs. (2015). Hungarikumok területi jelentőségének vizsgálata, különös tekintettel a pálinkára. Tér és Társadalom 29(4), 139-153. DOI: 10.17649/TET.29.4.2707.

[26] Kassai, Zs. (2012). A LEADER program mint helyi partnerség kérdései Magyarországon [PhD thesis]. Gödöllö: Szent István Egyetem.

[27] Kőszegfalvi, Gy. \& Loydl, T. (1999). Településfejlesztés. Budapest: ELTE Kiadó.

[28] Kovács, K. \& Szilágyi, D., eds. (2021). Tér-Kép, 2019. Budapest: Központi Statisztikai Hivatal.

[29] Kull, M. (2009). EU Multi-level Governance in the Making - The Community Initiative LEADER+ in Finland and Germany. Acta Politica 32.

[30] Lowndes, V., Lawrence, P. \& Stoker, G. (2001). Trends in Public Participation: Part 1 - Local Government Perspectives. Public Administration, 79(1), 205-222.

[31] Nagy, H. (2019a). A helyi gazdaság- és vállalkozásfejlesztés szerepe és lehetőségei a vidékbiztonság megteremtésében, Budapest: Nemzeti Közszolgálati Egyetem.

[32] Nagy, H. (2019b). Regional policy in practice in selected African, Asian and European countries, Rzeszów: Scientifical Society Social Space and Environment Al. 
[33] Nagyné Molnár, M. (2013). Factors of successincase of local society. Deturope: Central European Journal of Tourism and Regional Development, 5(3), 63-70. DOI: $10.1057 / 9780230247017 \_4$.

[34] Oláh, I. (2017). 1000 fö alatti települések vizsgálata Magyarországon [PhD thesis]. Gödöllö: Szent István Egyetem.

[35] Rechnitzer, J. \& Smahó, M. (2011). Területi politika. Budapest: Akadémiai Kiadó.

[36] Ritter, K., Nagy, H. \& Tóth, T. (2013). Hátrányos helyzetű vidéki térségek és helyi fejlesztési lehetőségeik egy Észak-magyarországi példán keresztül. In Lukovics, M. \& Savanya, P., eds., Új hangsúlyok a területi fejlődésben (pp. 224-242). Szeged: JATE Press.

[37] Salamin, G. (2018). Az Európai Unió térbeli stratégiáinak, tervezésének és kohéziós politikájának hatása az európai országok térbeli tervezési rendszereinek transzformációjára [PhD. Thesis]. Gödöllö: Szent-István Egyetem.

[38] Scott, M. (2004). Building institutional capacity in rural Northern Ireland: the role of partnership governance in the LEADER II programme. Journal of Rural Studies, 20(1), 4959. DOI: 10.1016/S0743-0167(03)00042-1.

[39] Shortall, S. (2008). Are rural development programmes socially inclusive? Social inclusion, civic engagement, participation, and social capital: Exploring the differences. Journal of Rural Studies, 24(4), 450-457. DOI: 10.1016/j.jrurstud.2008.01.001.

[40] Shucksmith, M. (2000). Endogenous Development, Social Capital and Social Inclusion: Perspectives from LEADER in the UK. Sociologia Ruralis, 40(2), 208-218. DOI: $10.1111 / 1467-9523.00143$.

[41] Sorensen, T. \& Epps, R. (1996). Leadership and local development: dimensions of leadership in four central Queensland towns. Journal of Rural Studies 12, 113-125. DOI: 10.1016/0743-0167(95)00052-6.

[42] Sorensen, T. (2002). Coolah's leadership. In Sorensen, T., Atchison, J., Argent, N., Archer, J., Jobes, P., Walmsley, D. \& Epps, R., eds., Telling the Coolah Story: towards Best Practice Regional Development (pp. 45-53). Armidale: University of New England.

[43] Storey, D. (1999). Issues of Integration, Participation and Empowerment in Rural Development: The Case of LEADER in the Republic of Ireland, Journal of Rural Studies, 15(3), 307-315. DOI: 10.1016/S0743-0167(98)00073-4.

[44] Szilágyi, T., Boldizsár, G. (2016). A biztonságos vidék, mint az állam létfeltétele. Pro Scientia Ruralis 1(4), 24-34.

[45] Taylor, M. (2000). Communities in the lead: power, organisational capacity and social capital. Urban Studies, 37(5-6), 1019-1035. DOI: 10.1080/00420980050011217.

[46] Thuesen, A. A. (2010). Is LEADER Elitist or Inclusive? Composition of Danish LAG Boards in the 2007-2013 Rural Development and Fisheries Programmes. Sociologia Ruralis, 50(1), 31-45. DOI: 10.1111/j.1467-9523.2009.00500.x.

[47] Tiner, T. (2008). Területfejlesztés, településfejlesztés. Komárno: Selye János Egyetem.

[48] Tóth, T. (2019). Sikeres/jó önkormányzati müködés gazdaságbiztonsági és szociális/társadalmi biztonsági dimenziói. Gödöllő: Szent István Egyetemi Kiadó.

\section{Other sources}

[49] Department of Local Government and Regional Development Western Australia, 2002: West Australian Community Leadership Plan. Retrieved 2 October, 2006 from www.wacommunityleadership.com.au.

[50] G. Fekete, É. (2011). A Nemzeti Vidékstratégia (2014-2020) hangsúlyai a vidéki népesség megélhetése, jövője szemszögéböl [unpublished presentation], retrieved from: 
https://mtvsz.hu/dynamic/g_fekete_eva_videkstrat_a_videki_nepesseg_megelhetese_jov oje_szemszogebol_2011_03_10.pdf.

[51] Kenyon, P. (1999). Don't wait for the cavalry it's 'do it yourself' time: an Australian community development perspective [unpublished keynote presentation to the Australian Regional Summit 1999].

[52] Kovács, G. (2006). Interjú Pásztor Béla polgármesterrel, www.origo.hu.

[53] McKinsey and Company (1994). Lead Local Compete Global: Unlocking the Growth Potential of Australia's Regions. McKinsey and Company, Sydney.

[54] OFTK (2014): Az Országgyülés 1/2014. (I. 3.) OGY határozata a Nemzeti Fejlesztés 2030 Országos Fejlesztési és Területfejlesztési Koncepció, MAGYAR KÖZLÖNY 1. szám MAGYARORSZÁG HIVATALOS LAPJA 2014. január 3. 